\title{
ПРЕИМУЩЕСТВА И НЕДОСТАТКИ СЕМЕЙНОЙ МЕДИАЦИИ В РОССИИ *
}

\author{
(C) 2019 Курмаева Наталья Анатольевна \\ доцент, кандидат юридических наук, доцент кафедры правовых дисциплин \\ Национальный исследовательский Мордовский государственный университет им. Н.П. Огарёва, \\ Россия, Саранск \\ E-mail: kurmaeva_n@mail.ru

\section{(c) 2019 Кулагина Мария Николаевна} \\ магистрант кафедры правовых дисциплин \\ Национальный исследовательский Мордовский государственный университет им. Н.П. Огарёва, \\ Россия, Саранск
}

Процедура медиации является наиболее предпочтительной формой урегулирования семейных споров. К числу ее главных преимуществ следует отнести безболезненность разрешения конфликта для всех его участников, учет интересов каждой стороны, в том числе несовершеннолетних детей, сохранение доброжелательных отношений между супругами при расторжении брака. Это особенно важно в семейных отношениях, поскольку расставание родителей негативно отражается на психике детей. В то же время, несмотря на множество положительных моментов, в нашей стране семейная медиация не находит широкого применения, в связи с чем авторами высказаны рекомендации о перспективных направлениях применения данной процедуры как альтернативного способа разрешения семейных споров. К проведению данной процедуры предложено привлекать психолога, что повысит ее результативность и обеспечит максимальную психологическую комфортность для лиц, в ней участвующих.

Ключевые слова: медиация, семейная медиация, процедура медиации, медиатор, семейный спор, семейные отношения, конфликт, стороны конфликта, медиативное соглашение.

Согласно ч. 1 ст. 38 Конституции РФ семья, материнство и детство находятся под защитой государства. В связи с этим необходимо укреплять институт семьи, стараться предотвращать случаи расторжения брака между супругами, защищать права и интересы детей, чему способствует внедрение и развитие процедуры семейной медиации. Применение медиативных процедур для урегулирования семейных конфликтов направлено на защиту семьи и детей.

Медиация - это добровольный способ урегулирования семейно-правового конфликта при активном содействии медиатора. Для проведения медиации необходимо добровольное согласие сторон. Результатом данной процедуры является достижение взаимоприемлемого решения, выраженного в медиативном соглашении.

В некоторых случаях медиация помогает предотвратить расторжение брака, в других существенно способствует урегулированию последствий расставания супругов, тем самым сохраняя дружественные отношения, взаимопо- нимание и сотрудничество между ними.

Посредством проведения процедуры медиации разрешаются семейные споры, возникающие между родителями и детьми, в том числе от другого брака, братьями и сестрами, супругами и их родителями, а также между супругами по вопросам усыновления (удочерения) ребенка, воспитания детей, ухода за престарелыми членами семьи и т.п. [4, С. 59].

Наиболее распространенной формой семейной медиации является медиация при бракоразводном процессе. В данном случае сталкиваются не только интересы взрослых людей, но и их стремление манипулировать своими детьми [1, C. 135-136]. Почти всегда это бывает необходимо для увеличения доли имущества, подлежащего разделу.

Главными преимуществами семейной медиации являются безболезненность разрешения конфликта для всех его участников, учет интересов каждой стороны, в том числе несовершеннолетних детей, сохранение доброжелательных отношений между супругами при расторжении

\footnotetext{
* Исследование выполнено при финансовой поддержке РФФИ в рамках научного проекта № 19-011-00570
} 
брака. Это особенно важно в семейных отношениях, поскольку расставание родителей негативно отражается на психике детей [3].

Как правило, при расторжении брака между супругами возникают конфликты, касающиеся раздела имущества, приобретенного совместно, о том, с кем будут проживать несовершеннолетние дети и об определении порядка общения с ними. Бывшие супруги, находясь в стрессовой ситуации под влиянием эмоций, не могут принять самостоятельное решение по вышеуказанным вопросам. В таком случае они вынуждены обратиться в суд. Споры, возникающие из брачно-семейных отношений, представляют особую сложность, их рассмотрение занимает длительное время, особенно в случаях, когда затрагиваются интересы несовершеннолетних детей.

В суде отношения супругов носят соперничающий характер, отличаются противоборством, каждый из них старается выиграть процесс. Причем одна из сторон всегда остается недовольна результатом судебного рассмотрения спора, поскольку считает, что решение суда не учитывает ее интересы. В результате решение суда очень трудно исполнить [2, С. 73].

Помощь посредника в бракоразводном процессе способна сгладить острые противоречия между бывшими супругами и выработать оптимальную модель урегулирования их взаимных претензий друг к другу.

Таким образом, можно перечислить основные характеристики медиации: конфиденциальность и добровольность проведения данной процедуры; самостоятельный выбор медиатора противоборствующими сторонами; его независимость и самостоятельность; учет индивидуально-психологических особенностей участников; возможность выражения своего мнения в целях поиска взаимоприемлемого решения; максимальный контроль сторон за осуществлением процедуры медиации.

Особая эмоциональность отличает семейную медиацию от других видов примирительных процедур, поскольку без выхода накопившихся друг к другу претензий и обид невозможно достижение компромисса и принятие взаимоприемлемого решения. При этом первостепенное значение имеют интересы несовершеннолетних детей. В семейных правоотношениях рекомендуется значительное внимание уделять индивидуально-психологическим особенно- стям их участников [5, С. 33].

Сложность процедуры разрешения споров между супругами состоит не только в необходимости применения норм семейного права, но и требуется достаточный уровень знаний возрастной и семейной психологии, педагогики и конфликтологии. В этой связи, учитывая имеющийся положительный зарубежный опыт [9, С. 456], к проведению данной процедуры следует привлекать психолога, что повысит результативность данной процедуры и обеспечит максимальную психологическую комфортность для ее участников.

При расторжении брака между супругами чаще всего страдают их несовершеннолетние дети. Выяснение отношений интересует родителей больше всего. С помощью детей они пытаются как можно больше обидеть друг друга, при этом задаривая ребенка подарками, наговаривая на плохого папу или маму или даже запугивая, не задумываются о том, что для него одинаково любимы и родны оба родителя. Спорящие супруги очень редко учитывают мнение своего ребенка, тем самым подвергая его стрессам, боязни потерять кого-то из родителей. Больнее всего на такие манипуляции реагируют подростки. Результатом может стать побег ребенка из дома, общение с девиантными сверстниками, курение, употребление спиртных напитков и даже наркотиков. Применение семейной медиации позволяет сторонам конфликта договориться наиболее благоприятным путем не только для себя, но и учесть наилучшие интересы своих детей.

Главная задача медиатора состоит в проведении переговоров, целью которых является поиск сторонами решения, которое будет являться компромиссным для обеих сторон.

Согласно п. 3 ч. 1 ст. 2 Федерального закона «Об альтернативной процедуре урегулирования споров с участием посредника (процедуре медиации)» от 27 июля 2010 года № 193-Ф3 «медиатор, медиаторы - независимое физическое лицо, независимые физические лица, привлекаемые сторонами в качестве посредников в урегулировании спора для содействия в выработке сторонами решения по существу спора».

Медиатор не принимает никаких обязательных решений, а лишь оказывает сторонам содействие в поиске наилучшего способа урегулировании спора. В ходе медиативного процесса субъекты конфликта обсуждают различные ва- 
рианты его разрешения и совместно выбирают наилучший из них [11, С. 54].

Как правило, семейная медиация проводится в несколько этапов:

1) обоюдное волеизъявление сторон на проведение процедуры медиации. При желании оно может подкрепляться заключением определенного соглашения;

2) поиск сторонами конфликта медиатора с последующим заключением договора о проведении медиации;

3) сбор и систематизация информации, полученной медиатором от сторон конфликта, их требования, а также выявление третьих лиц, участвующих в процессе, назначение даты, времени и места проведения беседы;

4) непосредственное проведение медиации, в ходе которой медиатор изучает и систематизирует информацию, полученную от сторон конфликта, а также третьих лиц, выявляет возможные риски и постепенно помогает сторонам конфликта достичь соглашение, устраивающее их;

5) достижение согласия между участниками семейного конфликта и заключение медиативного соглашения. Если при проведении медиации сторонам все же не удалось договориться о мирном разрешении спора, и медиативное соглашение ввиду ряда причин не было заключено, они вправе обратиться в суд.

По результатам проведения процедуры медиации заключаются следующие медиативные соглашения:

1) соглашение, предусматривающее порядок осуществления родительских прав родителем, проживающим отдельно от ребенка;

2) брачный договор, составляемый в письменной форме и подлежащий нотариальному удостоверению;

3) соглашение о разделе общего имущества супругов;

4) соглашение об уплате алиментов, определяющее размер, условия и порядок их выплаты, подлежащее нотариальному удостоверению.

В настоящее время медиативные соглашения приравниваются к мировым соглашениям, так как одинаковы по смыслу и объединены общей целью.

Семейная медиация не может применяться при выявлении случаев физического насилия, психического расстройства участников конфликта, злоупотребления ими спиртными на- питками и наркотическими средствами [4, С. 61].

Порядок проведения процедуры медиации, в том числе и по семейным спорам, регламентируется Федеральным законом «Об альтернативной процедуре урегулирования споров с участием посредника (процедуре медиации)» от 27 июля 2010 года № 193-Ф3. Но, несмотря на достаточно длительный период действия данного закона, семейная медиация до сих пор не находит широкого применения в России. Это обусловлено следующими факторами:

1) значительная стоимость услуг профессионального медиатора. В частности, по данным аналитического материала СПС «Гарант» один час работы медиатора оценивается примерно в две тысячи рублей [10, С. 23]. Учитывая, что примирение сторон одной процедурой не обойдется, сумма получается значительная, и не все граждане могут позволить оплатить данные услуги. K тому же нет никаких гарантий, что в итоге найдется компромисс и удастся заключить мировое соглашение. Что касается денежных трат при разбирательстве в суде, то сумма госпошлины при расторжении брака по состоянию на сегодняшний день составляет 600 рублей (п. 5 ч. 1 ст. 333.19 НК РФ) [8]. Разница очевидна. Кроме того, следует учитывать отсутствие серьезного государственного финансирования программ развития семейной медиации [5, С. 32];

2) пробелы в законодательстве о процедуре медиации. В Федеральном законе «Об альтернативной процедуре урегулирования споров с участием посредника (процедуре медиации)» не содержится точного регламента проведения данной процедуры, отсутствуют четко прописанные требования, предъявляемые к медиатору, не регламентированы его функции, не указано, что в ходе проведения процедуры приемлемо выполнять, что обязательно или строго запрещено;

3) отсутствие специализированных государственных центров медиации. Граждане с недоверием относятся к так называемым «конторам» оказания медиативных услуг и редко обращаются к услугам частных медиаторов;

4) отсутствие хорошей рекламы. Как известно, разрешить конфликт мирным путем возможно как до начала судебного разбирательства, так и на любой из его стадий. Судья разъясняет конфликтующим сторонам преимущества использования процедуры медиации, сообщает о возможности мирного разрешения спора с сохранением межличностных отношений. Но, к 
сожалению, не все знают о том, что можно обратиться к медиатору для содействия в разрешении семейного спора. Поэтому в средствах массовой информации следует как можно доступнее и понятнее разъяснить смысл и значение семейной медиации.

Таким образом, медиация представляет собой гибкий и действенный процесс, который направлен на достижение мирного урегулирования семейного конфликта с сохранением дружественных отношений между сторонами.

В научной литературе высказаны мнения об обязательности проведения процедуры медиации при разрешении семейно-правовых споров [7, С. 194]. Данное предложение, несомненно, будет способствовать сокращению количества дел, находящихся в производстве, снизит судебную нагрузку [6, С. 30]. Однако это противоречит до- бровольному характеру медиативной процедуры.

Тем не менее, следует активно развивать применение медиативных технологий при разрешении семейных конфликтов. Требуется создание специальных центров для подготовки квалифицированных медиаторов. Предпочтительнее создавать государственные службы, занимающиеся вопросами семейной медиации, для этого необходимо государственное финансирование. Значительное внимание следует уделять вопросам привлечения психолога для проведения медиации, так называемая процедура сомедиации. В субъектах Российской Федерации рекомендуется создать Службы судебных психологов, одним из направлений деятельности которых будет являться проведение медиации по семейным спорам.

\section{Библиографический список}

1. Бодрова Е.А. Современная форма семейной медиации в России и за рубежом // Вестник РГГУ. Серия: Экономика. Управление. Право.- 2015.- № 1 (144).- С. 134-137.

2. Буянова Е.В. Особенности процедуры медиации в семейных спорах: анализ зарубежного опыта // Труды Оренбургского института (филиала) Московской государственной юридической академии. - 2016.№ 30.- С. 71-79.

3. Вести образования.- 2015. - № 5 (114)._ URL: http://edition.vogazeta.ru/ivo/info/14517.html (дата обращения 13.09.2019)

4. Емелькина И.А. Семейная медиация при рассмотрении споров, вытекающих из семейных правоотношений // Применение процедуры медиации при рассмотрении гражданских дел в судах общей юрисдикции (методическое пособие).- Саранск, 2018.- С. 59-62.

5. Исаенкова О.В. Использование опыта Республики Беларусь и других государств для развития семейной медиации в России // Медиация в семейном конфликте: сборник материалов II Всероссийской научнопрактической конференции.-Саратов: Саратовский источник, 2018.-С. 30-35.

6. Куринова Л.Ю. Медиация - эффективный способ урегулирования семейных конфликтов // Применение процедуры медиации при рассмотрении гражданских дел в судах общей юрисдикции (методическое пособие).- Саранск, 2018.- С. 24-30.

7. Назинцева А.Ю. Современное состояние семейной медиации в России // Актуальные проблемы правового, социального и политического развития России: материалы X Международной научно-практической конференции студентов, магистрантов, аспирантов.- Саратов: Саратовский источник, 2017.- С. 192-195.

8. Налоговый кодекс Российской Федерации (часть вторая) от 05.08.2000 г. № 117-ФЗ (ред. от 30.07.2019).URL: http://www.consultant.ru/document/cons_doc_LAW_28165/84d383b088ff6ad7be9ba16d43c71828b1105aa5 (дата обращения 13.09.2019)

9. Пантеева И.А. Семейная медиация как альтернативная процедура разрешения споров // Вестник ННГУ.2014. - № 1.- С. 452-457.

10. Смелкова Г.Ф. Проблемы интеграции процедуры медиации в гражданский процесс // Применение процедуры медиации при рассмотрении гражданских дел в судах общей юрисдикции (методическое пособие).Саранск, 2018.- С. 17-30.

11. Худойкина Т.В. Основные характеристики и стадии медиативного процесса // Применение процедуры медиации при рассмотрении гражданских дел в судах общей юрисдикции (методическое пособие).-Саранск, 2018.- C. 48-55. 